\title{
Evaluation of translucency of a nanofilled and a microhybrid resin composites
}

Avaliação da translucência de resinas compostas nanoparticuladas e microhíbridas

Fabiana Mezzaroba Ortenzi GRACIANO

DDS - MS - Department of Operative Dentistry - University North of Paraná - Londrina - Paraná - Brazil.

João Tadeu Amin GRACIANO

DDS - MS - Department of Operative Dentistry - University North of Paraná - Londrina - Paraná - Brazil.

Larissa Pincelli CHAVES

DDS - MS - Dentistry Department - Division of Dental Materials Paranaense University UNIPAR - Cascavel - Paraná - Brazil.

Terezinha de Jesus Esteves BARATA DDS - MS - PhD - Department of Operative Dentistry - School of Dentistry - Federal University of Goiás - Goiânia - Goiás - Brazil.

Regina Guenka PALMA-DIBB DDS - MS - PhD - Department of Operative Dentistry - Endodontics and Dental Materials - Ribeirão Preto School of Dentistry - University of São Paulo - Bauru - SP - Brazil.

Linda WANG DDS - MS - PhD - Department of Operative Dentistry - Endodontics and Dental Materials - Bauru School of Dentistry - University of São Paulo - Bauru - SP - Brazil.

\begin{abstract}
Objectives: Color selection is a relevant issue to determine clinical success of esthetic restorations. However as multiple layer technique have been applied, opalescence and translucency parameters are also significant to allow resin composite to match tooth structure. Thus, the aim of this study was to compare different resin composites commonly launched in market to provide enamel translucency effect. Material and Methods: Four resin composites of shade A1 for enamel were tested: nanotechnology composites Filtek Z350 (F) and Grandio (G) were compared to microhybrid composites Filtek Z250 (Z) and Master Fill (M). Eight cylindrical specimens of each resin composite were prepared (6 $\mathrm{mm} \times 2.5 \mathrm{~mm})$, finished and individually stored in distilled water. The color analysis was performed following Cielab system parameters using a spectophotometer (Esfera-X-Rite-SP62 and X-Riteccolor Master CM2). Readings were processed using standard white and black backgrounds. Translucency parameter (TP) of these materials were calculated through the formula $\mathrm{TP}=[(\mathrm{Lw}-$ $\left.\mathrm{Lb})^{2}+(\mathrm{aw}-\mathrm{ab})^{2}+(\mathrm{bw}-\mathrm{bb})^{2}\right]^{1 / 2}$. Data were statistically analyzed and as a normal distribution was verified, they were submitted to oneway ANOVA and Tukey tests with $\alpha=0.05$ preset. Results: Mean and standard deviations were: $F=35.54+0.34 ; Z=39.11+0.39 ; G=$ $40.93+0.38$ e $\mathrm{M}=41.41+0.34$. Greater values of translucency were observed to $\mathrm{G}$ and $\mathrm{M}$ without significant differences between them, and the lower values were attributed to $\mathrm{F}$ and $\mathrm{Z}$. Conclusion: The translucency of each material was material dependent. It is suggested that small particle size provokes reduction of translucency of resin composites when enamel shade materials are compared.
\end{abstract}

\section{RESUMO}

Objetivos: A seleção de cor é um aspecto relevante na determinação do sucesso clínico de restaurações estéticas. Entretanto, como a técnica laminada múltipla tem sido aplicada, parâmetros de opalescência e translucência também são significantes para permitir que a resina composta se mimetize à estrutura dentária. Desta forma, o objetivo deste estudo foi comparar diferentes resinas compostas comumente disponíveis comercialmente para oferecer o efeito de translucência do esmalte. Material e Metódos: Quatro resinas compostas da cor A1 para esmalte foram testadas: resinas nanoparticuladas Filtek Z350 (F) e Grandio $(G)$ foram comparadas às resinas microhíbridas Filtek Z250 (Z) e Master Fill (M). Oito espécimes cilindricos de cada resina composta foram preparadas ( $6 \mathrm{~mm} \times 2.5 \mathrm{~mm}$ ), polidas e individualmente armazenadas em água destilada. A análise da cor foi realizada seguindo os parâmetros do sistema Cielab, utiizando um espectofotômetro (Esfera -X-Rite-SP62 and X-Riteccolor Master CM2). As leituras foram processadas usando fundos padronizados branco e preto. O parâmetro de translucência (TP) desses materiais foi calculado através da fórmula $\mathrm{TP}=\left[(\mathrm{Lw}-\mathrm{Lb})^{2}+(\mathrm{aw}-\mathrm{ab})^{2}+(\mathrm{bw}-\mathrm{bb})^{2}\right]^{1 / 2}$. Os dados foram analisados estatisticamente e como foi verificada uma distribuição normal, estes foram submetidos ao teste de ANOVA e Tukey $\alpha=0,05$. Resultados: Médias e desvios-padrão foram: $\mathrm{F}=35,54+0,34 ; \mathrm{Z}=$ $39,11+0,39 ; \mathrm{G}=40,93+0,38$ e $\mathrm{M}=41,41+0,34$. Maiores valores de translucência foram observados para $\mathrm{G}$ e $\mathrm{M}$ sem diferenças entre eles, e os menores valores foram atribuídos para F e Z. Conclusão: A translucência de cada resina é dependente do material. É sugerido que tamanho pequeno de partículas provoca uma redução da translucência das resinas compostas quando as cores de esmalte são comparadas.

\section{Palavras-Chave}

Estética; Nanotecnologia; Resina composta; Translucência. 


\section{INTRODUCTION}

Since the introduction of resin composites, they have been widely applied mainly due to their ability to blend with surrounding teeth [1]. Strong efforts have been made to provide satisfactory mechanical properties to make them indicated even to posterior teeth restorations [2,3]. Clinical trials confirm that available resin composites present acceptable performance in oral service in the anterior and posterior region, which is a more mechanical stressed area $[3,4]$. Since then, different organic matrix and filler characteristics have been investigated, which implies in relevant modifications [5-7]. In the last years, nanotechnology materials were introduced, and studies to verify their performance have been conducted [4,8-11].

However, despite the valuable mechanical properties stated in laboratorial and clinical trials, esthetic properties consist in an essential parameter to determine clinical success [12-14]. The adjunctive properties would, at last instance, be able to provide long-term successful treatment. Correct shade selection of the resin composites is one of the most difficult challenges in esthetic restorations, mainly in anterior teeth $[15,16]$. Besides croma, hue and value, other attributions as opalescence, fluorescence and translucency are also considered to obtain the more adequate material or their association [12-22]. Translucency is defined as an optical property associated to the ability to permit light transmission or not $[5,12,13,21,22]$. A more translucent material allows more light transmission, which is the opposite of an opaque material. However, translucent material do not only permits the passage of light but disperses it. So translucency can be described as partial opacity or a state between complete opacity and complete transparency [22].

Human eyes are able to recognize details of the color and a mismatched translucency can compromise overall the successfulness of the treatment. For instance, a common clinical error is when a translucent material is used to restore incisal line of incisors of elder or patients greatly compromised by wear. Stratification layers of resin-based restorations are usually reconstructed with translucent material, which is called enamel-shaded resin composites [23].

Nanofilled material were developed based on technology to support greater mechanical resistance and a long-term polishing durability according to manufacturers $[4,8,9]$. Additionally, the reduced size of these particles can allow distinct light distribution, affecting optical features [6].
Thus, this study DP HGH comparing the translucency of four resin composites of different categories in order to analyze the effect of particle dimension on the distribution of light. The null hypothesis is that there is no influence of particle on the translucency of different resin composites.

\section{MATERIAL AND METHOdS}

This experimental design involved one factor (enamel-shaded resin composites) in four levels, compared by means of translucency. Four different resin composites were tested in this study, categorized as presented in Table 1 .

\section{TABLE 1- REsin COMPosites UNDER TEST}

\begin{tabular}{|c|c|c|c|}
\hline Material & Category & Manufacturer & Composition \\
\hline $\begin{array}{c}\text { Filtek } \\
\text { Z350 } \\
(F)\end{array}$ & Nanofilled & $\begin{array}{l}\text { 3M ESPE, } \\
\text { Dental } \\
\text { Products, St. } \\
\text { Paul, MN, } \\
\text { USA }\end{array}$ & $\begin{array}{c}\text { Matrix: Bis-GMA, Bis- } \\
\text { EMA, TEGMA, } \\
\text { Filler: } 20 \mathrm{~nm}, 5-20 \mathrm{~nm} \\
\text { (0.6 to } 1.4 \mathrm{~mm} \text { cluster) } \\
\text { Zirconia/Silica and } \\
\text { Sílica }(78.5 \% \mathrm{w} / \mathrm{w}, \\
59.5 \% \mathrm{v} / \mathrm{v})\end{array}$ \\
\hline $\begin{array}{c}\text { Grandio } \\
\text { (G) }\end{array}$ & Nanohybrid & $\begin{array}{l}\text { Voco, } \\
\text { Cuxhaven, } \\
\text { Germany, }\end{array}$ & $\begin{array}{c}\text { Matrix: Bis-GMA, } \\
\text { dimethacrylate, UDMA, } \\
\text { TEGMA } \\
\text { Filler: silicium dioxide } \\
\text { nanofillers }(20-50 \mathrm{~nm}) \\
\text { and glass ceramic } \\
\text { microfillers }(87 \% \mathrm{w} / \mathrm{w}, \\
71.4 \% \mathrm{v} / \mathrm{v})\end{array}$ \\
\hline $\begin{array}{l}\text { Master } \\
\text { Fill } \\
\text { (M) }\end{array}$ & Microhybrid & $\begin{array}{c}\text { Biodinâmica, } \\
\text { Ibiporã, PR, } \\
\text { Brazil }\end{array}$ & $\begin{array}{c}\text { Matrix: Bis-GMA, } \\
\text { UEDMA and TEGDMA } \\
\text { dimethacrylates } \\
\text { monomers; pigments } \\
\text { (Titanium Dioxide } \\
\text { and Iron Oxide) } \\
\text { and initiator agent } \\
\text { (camphorquinone), } \\
\text { viscosity controllers } \\
\text { Filler: inorganic charge } \\
\text { particles of Boron- } \\
\text { silicate of Barium- } \\
\text { aluminum glass, silica } \\
\text { of average size } 0.6 \mathrm{~mm} \\
(79 \% \mathrm{v} / \mathrm{v}) .\end{array}$ \\
\hline $\begin{array}{c}\text { Filtek } \\
\text { Z250 } \\
(Z)\end{array}$ & Microhybrid & $\begin{array}{l}\text { 3M ESPE, } \\
\text { Dental } \\
\text { Products, St. } \\
\text { Paul, MN, } \\
\text { USA }\end{array}$ & $\begin{array}{c}\text { Matrix: Bis-GMA, Bis- } \\
\text { EMA, UDMA } \\
\text { Filler: Zirconia/Silica } \\
\text { (82\%w/w, } 60 \% \mathrm{v} / \mathrm{v}) \\
\text { Particle size range of } \\
0.01 \text { to } 3.5 \mu \mathrm{m} \text {. }\end{array}$ \\
\hline
\end{tabular}

BIS-GMA = Bisphenol-A-glycidyl methacrylate; BISEMA = Ethoxylated bisphenol-A-glycidyl methacrylate; TEGDMA = Triethylene glycol dimetacrylate; UDMA = Urethane dimetacrylate; UDEMA= Ethoxylated urethane dimetacrylate. 
All materials were analyzed using A1 for enamel shade. For each material, eight cylindrical specimens $(6 \mathrm{~mm} \times 2.5 \mathrm{~mm})$ were prepared. An increment of resin was directly inserted into a stainless steel matrix filling it completely, and a little bit of excess was extruded. Air-bubbles were eliminated and a polyester strip was placed over the resin composite and covered with a glass slide under constant pressure of $200 \mathrm{~g}$ for $30 \mathrm{~s}$. Afterwards, specimens were lightcured according to manufacturer's instructions on both sides using a halogen lamp (Optilight Plus Gnatus, Ribeirão Preto, SP, Brazil). Irradiance of the curing unit was $400 \mathrm{~mW} / \mathrm{cm} 2$, which was measured by means of a radiometer (Curing radiometer, Model 100P/N-150503 - Demetron Research Corp., Danbury, CT, USA).

Thereafter, the specimens were individually stored in water at $37^{\circ} \mathrm{C}$ for $24 \mathrm{~h}$. The samples were polished with \# 600 and \# 1200 granulation-disks under water cooling. $0.25 \mu \mathrm{m}$ diamond particle solution was applied with filter tissues as a final step. Finally, samples were cleaned ultrasonically (Tempo Ultrasonic Ind. Com. LTDA, Taboão da Serra, SP, Brazil, model T-14,90 W) in deionized water for $10 \mathrm{~min}$ to remove the polishing debris. The thickness of each specimen was measured using a digital electronic caliper (Mitutoyo Corporation, Tokyo, Japan).

The translucency analysis was performed following Cielab system using a spectophotometer (Esfera -X-Rite-SP62 and X-Riteccolor Master CM2), wherein L represents the value from 0 (black) to 100 (white) and $\mathrm{a}^{*}$ and $\mathrm{b}^{*}$ represent the shade, where $a^{*}$ is the measurement along the red-green axis and $b^{*}$ is the measurement along the yellowblue axis. Readings were processed using standard white and black backgrounds and randomized triplicate measurements of each surface were obtained. Translucency (TP) of these materials were calculated through the formula $\mathrm{TP}=\left[(\mathrm{Lw}-\mathrm{Lb})^{2}+\right.$ $\left.(a w-a b)^{2}+(b w-b b)^{2}\right]^{1 / 2}$, where subscript $w=$ white and $\mathrm{b}=$ black.

The assumptions of equality of variances and normal distribution of errors were checked for the tested response variables. Since the assumptions were satisfied, data were submitted to one-way ANOVA and Tukey post hoc test $(\mathrm{p}<0.05)$.

\section{Results}

Means and standard deviations of translucency of tested materials are presented in Table 2 .
Table 2 - Means and Standard deViations of TRANSLUCENCY AMONG TESTED RESIN COMPOSITES

\begin{tabular}{c|c|c|c}
\hline Materials & Average & Standard error & Tukey test* $^{*}$ \\
\hline Filtek Z350 & 35.54 & 0.34 & $\mathrm{~A}$ \\
\hline Filtek Z250 & 39.11 & 0.39 & $\mathrm{~B}$ \\
\hline GrandIO & 40.93 & 0.38 & $\mathrm{C}$ \\
\hline MAster FIlL & 41.41 & 0.34 & $\mathrm{C}$ \\
\hline
\end{tabular}

$\mathrm{N}=8$; *Different uppercase letter denotes statistical differences among materials $(p<0.05)$

Greater values of translucency were observed to $G$ and $M$ without significant differences between them, and the lower values were attributed to $\mathrm{F}$ and $\mathrm{Z}$.

\section{Discussion}

In the beginning, resin composites were considered esthetic materials only due to their white appearance, even being visually perceptible as a restoration. Today, esthetic demand claimed for the patients who do not accept minimal perception $[15,16]$. It strongly means that not only the main color matches, but also their attributions as translucency, superficial texture, correct contours and other aspects to reproduce natural aspect are essential to provide satisfactory reproduction $[5,15,16,21,22]$.

A complex structure is established when fillers are introduced into a mixture of monomers as organic matrix and bonded through a silanization process [4]. It is known that the recent changes in filler and organic constituents and combinations have been minimized issues that commonly affect resin-based materials [21-25]. When any alteration modifies this complex, not only mechanical features are compromised but also optical properties [1,22].

In order to obtain the best visual harmony, additives have been introduced into resin composite. When these materials are clinically handled using incremental technique, not only the negative effects of polymerization shrinkage can be minimized. Stratification process with different optical properties of resin composites provides a combination to mimic dental tissues [15,16,23].

According to the results of the present study, it can be demonstrated that resin composites with reduced dimension of particle showed minimized translucency compared to resin composites with greater size. Even Grandio is classified as a nanofilled material, its particles are nanohybrid, with greater size compared to Filtek Z350. On the other hand, besides the 
classification of Filtek Z250 as a microhybrid resin composite, its particles denote small sizes that also result in minor translucency according to the results.

This analysis suggests that reduced dimensions of particles facilitate light to reflect, which minimize its ability to transmit to other side. However, care has to be taken, as filler size is not the only different attribution among tested resin composites. If no opaque agent is added it will result in a less translucent material. In the present study, as all resin composites are enamel-shaded, no opaque agent strongly interfered in the result. It was intentionally selected to create conditions to evaluate the influence of the filler in this optical property. If opaque shades for dentin were evaluated in a first instance, this component would interfere in this analysis, which would compromise the actual influence of fillers. However, as photoinitiator and related aspects due to photocuring process occur, they also interfere with the final performance of optical properties, mainly due to the yellow component influences [24-27]. Distinct perception is also a consequence according to background and measurement modes, thus they are helpful to guide color selection and not to be mandatory to clinical choice [28].

Under clinical service, the materials are submitted to deleterious conditions that modify their texture, which can provoke color modifications due to degradation of organic matrix, loss of particle, or the association of both reactions [29,30]. All this mechanism can negatively affect the superficial texture, highlighting the presence of a restoration and compromising the durability of the materials $[17,30]$.

Thus, it is licit to say that if no opaque component is considered, greater size of particles seems to contribute to higher translucency. When an esthetic restoration is performed, practitioners not only have to be aware of the main shade selection, but also to be aware of their translucency and the thickness of their superficial layers, in order to offer natural reproduction of the teeth aspect. The available commercial resin composites can offer a great variability of shades and also according to specific features such as translucency. Therefore, if professionals respect these details, great functional and esthetic results can be obtained.

\section{Conclusion}

It is suggested that small particle size provokes reduction of translucency of resin composites when enamel shade materials are compared. Enamelshaded resin composites promote different effect of translucency, which requires special attention from practitioners, in order to restore teeth with natural aspect. As this is often applied as a final layer, the choice of this material may be determinant to the esthetic treatment success.

\section{ACKNOWLedgments}

Authors are grateful to Biodinâmica, 3M ESPE and Voco for material donation

\section{References}

1. $\mathrm{Lu} \mathrm{H}$, Lee YK, Oguri M. Properties of a dental resin composite with a spherical inorganic filler. Oper Dent 2006;31(6):734-40.

2. Kovarik RE. Restoration of posterior teeth in clinical practice: evidence base for choosing amalgam versus composite. Dent Clin North Am 2009;53(1):71-6.

3. Kiremitci A, Alpaslan T, Gurgan S. Six-year clinical evaluation of packable composite restorations. Oper Dent 2009;34(1):11-7.

4. Mahmoud SH, El-Embaby AE, AbdAllah AM, Hamama HH. Two-year clinical evaluation of ormocer, nanohybrid and nanofill composite restorative systems in posterior teeth. J Adhes Dent 2008;10(4):315-22.

5. Kim JH, Lee YK, Powers JM. Influence of a series of organic and chemical substances on the translucency of resin composites. J Biomed Mater Res B Appl Biomater 2006; 77(1):21-7.

6. Kim JJ, Moon HJ, Lim BS, Rhee SH, Yang HC. The effect of nanofiller on the opacity of experimental composites. J

Biomed Mater Res B Appl Biomater 2007;80(2):332-8.

7. Yu B, Lee YK. Differences in color, translucency and fluorescence between flowable and universal resin composites J Dent 2008;36(10):840.

8. Duke ES. Has dentistry moved into the nanotechnology era? Compend Contin Educ Dent 2003;24(5):380-2.

9. Davis N. A nanotechnology composite. Compend Contin Educ Dent 2003;24(9):662-70.

10. Jung M, Eichelberger K, Klimek J. Surface geometry of four nanofiller and one hybrid composite after one-step and multiple-step polishing. Oper Dent 2007;32(4):347-55.

11. Yesil ZD, Alapati S, Johnston W, Seghi RR. Evaluation of the wear resistance of new nanocomposite resin restorative materials. J Prosthet Dent 2008; 99(6):435-43.

12. Baratieri LN, Araujo E, Monteiro S Jr. Color in natural teeth and direct resin composite restorations: essential aspects. Eur J Esthet Dent 2007; 2(2):172-86.

13. De Araujo EM Jr, Fortkamp S, Baratieri LN. Closure of diastema and gingival recontouring using direct adhesive restorations: a case report. J Esthet Restor Dent 2009;21(4):229-40. 
14. Hickel R, Roulet JF, Bayne S, Heintze SD, Mjör IA, Peters $\mathrm{M}$, et al. Recommendations for conducting controlled clinical studies of dental restorative materials. Science Committee Project 2/98--FDI World Dental Federation study design (Part I) and criteria for evaluation (Part II) of direct and indirect restorations including onlays and partial crowns. J Adhes Dent 2007;9 Suppl 1:121-47. Review. Erratum in: J Adhes Dent 2007;9:546.

15. Dietschi D, Ardu S, Krejci I. A new shading concept based on natural tooth color applied to direct composite restorations. Quintessence Int 2006;37(2):91-102.

16. Nahsan FP, da Silva LM, Baseggio W, Franco EB, Francisconi PA, Mondelli RF et al. Conservative approach for a clinical resolution of enamel white spot lesions. Quintessence Int 2011;42(5):423-6.

17. Lee YK, Lu H, Oguri M, Powers JM. Changes in gloss after simulated generalized wear of composite resins. J Prosth Dent 2005; 94(4):370-6.

18. Svizero NR, Alonso RCB, Wang L, Palma-Dibb RG, D'Alpino PHP. Kinetic of water diffusion and color stability of a resin composite as a function of the curing tip distance. Mater Res 2012;15(4):603-10.

19. Ota M, Ando S, Endo H, Ogura Y, Miyazaki M, Hosoya Y. Influence of refractive index on optical parameters of experimental resin composites. Acta Odontol Scand 2012;70(5):362-7.

20. Lee YK, Lu H, Powers JM. Influence of fluorescent and opalescent properties of resin composites on the masking effect. J Biomed Mater Res B Appl Biomater 2006;76(1):26-32.

21. Yu B, Lee YK. Translucency of varied brand and shade of resin composites. Am J Dent 2008;21(4):229-32.

22. Sidhu SK, Ikeda T, Omata Y, Fujita M, Sano H. Change of color and translucency by light curing in resin composites. Oper Dent 2006;31(6):598-603.

23. Terry DA. Developing natural aesthetics with direct composite restorations. Pract Proced Aesthet Dent. 2004;16(1):45-52.

24. Anfe TEA, Caneppele TMF, Agra CM, Vieira GF. Microhardness assessement of different commercial brands of resin composites with different degrees os translucence. Braz Oral Res 2008;22(4):358-63.

25. Schneider LF, Cavalcante LM, Consani S, Ferracane JL. Effect of co-initiator ratio on the polymer properties of experimental resin composites formulated with camphorquinone and phenyl-propanedione. Dent Mater 2009;25(3):369-75.

26. Paravina RD, Ontiveros JC, Powers JM. Curing-dependent changes in color and tranluscency parameter of composite bleach shades. J Esthet Restor Dent 2002;14(3):158-66.

27. Janda R, Roulet JF, Kaminsky $M$ et al. Color stability of resin matrix restorative materials as a function of the method of light activation. Eur J Oral Sci 2004;112(3):280-5.

28. Lee YK, Lim SB, Kim CW, Powers JM Color characteristics of low-chroma and high-translucence dental resin composites by different measuring modes. J Biomed Mater Res B Appl Biomater 2001; 58(6):613-21.

29. O'Brien WJ, Yee J Jr. Microstructure of posterior restorations of composite resin after clinical wear. Oper Dent 1980;5(3):90-4.

30. Colucci V, dos Santos CD, do Amaral FLB et al. Influence of $\mathrm{NaHCO} 3$ powder on translucency of microfilled composite resin immersed in different mouthrinses. J Esthet Restor Dent 2009; 2(4)1:242-8.

Received: 2012 Oct. 28 Accepted:2012 Dec. 17

Corresponding author:

Linda Wang Department of Operative Dentistry, Endodontics and Dental Materials -FOB-USP Alameda Octávio Pinheiro Brisolla, 9-75, 17012-901 BauruSP, Brazil Phone: +55-14-3235-8480/ fax: +55-14-3235-8323 e-mail: wang.linda@usp.br 